\title{
Faktor-Faktor yang Mempengaruhi Pembiayaan Berbasis Bagi Hasil (Profit And Loss Sharing)
}

\author{
Wahyuli Ambarwati Wulandari \\ Kiswanto \\ Jurusan Akuntansi, Fakultas Ekonomi, Universitas Negeri Semarang \\ Email:kiswantofeunnes@yahoo.com
}

\begin{abstract}
The purpose of this study was to examine the effect mudharaba deposits, return, profit-sharing rate and the average interest rate loans to profit and loss sharing of Islamic banks either simultaneously or partially. The population is Islamic bank in Indonesia, which consisted of 11 banks with a sample consisting of 7 Islamic banks. Criteria for selection of the sample is using purposive sampling. The unit of analysis is a semi-annual publication of the financial statements of Islamic banks in 2010-2012. The method of data analysis used in this study is multiple linear regression. Variables mudharaba deposits, return, profit sharing rate and the average interest rate are significant effect simultaneously to the profit sharing. While partially only variable mudaraba deposits, profit -sharing and profit sharing rate is significant positive effect on the profit and loss sharing. Meanwhile, the average interest rate credit does not significantly influence the profit and loss sharing.
\end{abstract}

Keywords: Mudharaba Deposits, Return, Profit Sharing Rate, Average Interest Rate, Profit and Loss Sharing.

\section{PENDAHULUAN}

Keberadaan bank syariah memiliki kontribusi positif dalam pertumbuhan perbankan di Indonesia. Hal ini nampak dari krisis moneter tahun 1998 yang melanda Indonesia mengakibatkan banyak bank konvensional jatuh, tetapi perbankan syariah dapat menunjukkan kinerjanya dan bahkan bahkan mampu memperlihatkan perkembangan yang cukup signifikan. Posisi perbankan syariah semakin diperkuat dengan fatwa bunga bank haram yang dikeluarkan oleh Komisi Fatwa Majelis Ulama Indonesia (MUI) 16 Desember tahun 2003. Ketentuan Bank Indonesia No. 7 Tahun 1992 yang diperbarui dengan Undang-undang No. 10 Tahun 1998 tentang bank dengan prinsip bagi hasil, mendapatkan respon yang sangat baik, yaitu memberikan kesempatan dalam pengembangan jaringan perbankan syariah.

Langkah yang ditempuh antara lain adalah pemberian izin pembukaan Unit Usaha Syariah (UUS) oleh bank umum konvensional, atau konversi sebuah kantor cabang atau sebuah bank konvensional menjadi bank syariah. Perkembangan perbankan syariah juga semakin didukung dengan disahkannya Undang-Undang No. 21 Tahun 2008 pada tanggal 16 Juli 2008. Semakin jelasnya peraturan tentang Perbankan Syariah diharapkan dapat meningkatkan perekonomian Indonesia dan meningkatkan kesejahteraan masyarakat karena perbankan syariah memiliki karakteristik unik, yaitu berperan dalam mendukung sektor sosial, di samping fungsi utamanya sebagai lembaga komersial (Rukmana dan Amir 2010:73). Perkembangan perbankan syariah dapat dilihat dari jaringan kantor perbankan syariah dan asset serta dana pihak ketiga yang terus meningkat.

Peran perbankan syariah sebagai lembaga keuangan memiliki fungsi yang sama dengan perbankan konvensional yaitu fungsi intermediasi keuangan. Bank

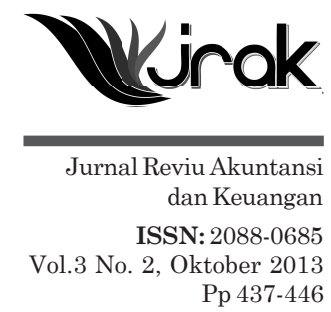


Faktor-

Faktor yang

Mempengaruhi
Syariah menghimpun dana dari masyarakat yang kelebihan dana dan menyalurkan kembali dana tersebut kepada masyarakat yang kekurangan dana. Karim (2007) produk yang ditawarkan oleh perbankan syariah dibagi menjadi tiga besar, yaitu produk penyaluran dana (financing), penghimpunan dana (funding) dan produk jasa (service). Ada beberapa macam skim pembiayaan (penyaluran dana) yang disalurkan oleh perbankan syariah, seperi skim jual beli, sewa, dan bagi hasil. Pembiayaan yang disalurkan oleh perbankan syariah dengan skema jual beli antara lain adalah murabahah, salam, dan istishna. Sedangkan untuk skema bagi hasil antara lain adalah mudharabah, musyarakah, muzara'ah dan musaqah (Antonio, 1999:129). Tetapi skema bagi hasil yang sering dipakai oleh perbankan syariah di Indonesia adalah musyarakah dan mudharabah.

Syariah Enterprise Theory menjelaskan bahwa Allah Subhanahu Wata'ala (SWT). Allah SWT sebagai pusat segala sesuatu dan menjadi pusat tempat kembalinya manusia dan alam semesta. Oleh karena itu, manusia di sini hanya sebagai wakil Allah (khalifatul fil ardh) yang memiliki konsekuensi untuk patuh terhadap semua hukum-hukum Allah dalam membawa misi menciptakan dan mendistribusikan kesejahteraan bagi manusia dan alam. Teori ini menyatakan bahwa harta adalah milik Allah dan hanya titipan untuk manusia dan harus dikelola sebaik mungkin. Harta yang dimiliki tidak boleh ditimbun dan harus dikelola dengan baik agar harta tersebut dapat berputar, produktif dan bermanfaat bagi orang lain. Peran perbankan syariah yang menjalankan segala kegiatannya berdasarkan aturan Al-Quran dan Hadist, sehingga perlu untuk bank syariah menyalurkan dana yang dihimpun sebagai pembiayaan kepada pihak lain yang membutuhkan.

Perkembangan trend pembiayaan bank syariah yang terjadi dari tahun ke tahun menunjukkan bahwa pembiayaan jual beli (murabahah) mendominasi pembiayaan berbasis bagi hasil (mudharabah dan musyarakah) dan pembiayaan lainnya. Menurut data yang disajikan pada Outlook Perbankan Syariah Indonesia (2013) hingga pada awal tahun 2013 porsi pembiayaan murabahah masih mendominasi pembiayaan perbankan syariah. Total pembiayaan murabahah yang disalurkan oleh perbankan syariah mencapai total 59,71\% (Rp 80,95 Trilliun), sedangkan pembiayaan berbasis bagi hasil sebesar $34,1 \%$, yakni pembiayaan mudharabah sebesar 8,44\% (Rp 11,44 Trilliun) dan pembiayaan musyarakah sebesar 18,59\% (Rp 25,21 Trilliun) serta piutang al Qardh sebesar 8,25\% (Rp 11,19 Trilliun). Masih rendahnya porsi pembiayaan bagi hasil atau mendominasinya pembiayaan non bagi hasil terutama jual beli (murabahah) merupakan fenomena global, tidak terkecuali di Indonesia. Menurut Ascarya dan Diana (2005:11-15) komposisi pembiayaan di Sudan 2003, menunjukkan mudharabah (6,9\%), musyarakah (23,4\%), murabahah (36,7\%) dan lainnya (33\%). Sedangkan komposisi pembiayaan di Malaysia, Juni 2004, menunjukkan mudharabah dan musyarakah (0,5\%), murabahah dan ba'i bitsaman ajil (53,1\%), hire purchase $(27,2 \%)$ dan lainnya $(10,2 \%)$.

Hal ini patut disayangkan karena total dari pembiayaan berbasis bagi hasil lebih kecil dari total pembiayaan dengan prinsip jual beli. Hal tersebut merupakan fenomena yang menarik karena diharapkan pembiayaan dengan berbasis bagi hasil yang mendominasi. Idealnya, pembiayaan berbasis bagi hasil pada perbankan syariah lebih mendominasi dibanding dengan pembiayaan lainnya. Hal ini dikarenakan pembiayaan berbasis bagi hasil lebih menjunjung nilai dan spirit islam dibanding dengan pembiayaan jual beli atau yang lainnya. Prinsip bagi hasil diharapkan lebih menggerakkan sektor riil karena menutup kemungkinan disalurkannya dana untuk kepentingan konsumtif dan ditujukan hanya untuk kepentingan produktif. Bila ditinjau dari konsep bagi hasil, maka harus ada return yang harus dibagi dan itu terjadi apabila uang yang digunakan untuk usaha produktif.

Terdapat berbagai macam faktor yang mempengaruhi pembiayaan yang dilakukan oleh perbankan syariah, dimana sesuai dengan Syariah Enterprise 
Theory diantaranya: deposito mudharabah, keuntungan bagi hasil, tingkat bagi hasil dan suku bunga rata-rata kredit. Penelitian yang dilakukan oleh Asyari (2004), Pratin (2005), Maryanah (2006), Hilmi (2006) dan Andraeny (2011) terkait dana pihak ketiga utamanya deposito mudharabah menunjukkan hasil berpengaruh signifikan, sedangkan penelitian Anggraeni (2005) menunjukkan hasil yang tidak berpengaruh signifikan.

Anggraeni (2005) dan Maryanah (2006) meneliti tentang keuntungan bagi hasil dan tingkat bagi hasil terhadap pembiayaan menujukkan hasil yang berpengaruh signifikan. Penelitian sebelumnya mengenai tingkat bagi hasil yaitu oleh Ambarwati (2008) dan Andraeny (2011) yang hasilnya berpengaruh signifikan dan Pratin (2005) dengan hasil tidak berpengaruh signifikan. Adanya ketidakkonsistenan hasil dari penelitian sebelumnya cukup menarik untuk dijadikan penelitian berikutnya.

Selanjutnya, suku bunga rata-rata kredit adalah salah satu variabel yang dipakai dan dapat menggambarkan kondisi makroekonomi dalam penyaluran pembiayaan pada perbankan konvensional di Indonesia. Diharapkan semakin tinggi suku bunga rata-rata kredit maka semakin tinggi pembiayaan berbasis bagi hasil yang disalurkan. Penelitian sebelumnya mengenai tingkat bagi hasil yaitu oleh Asyari (2004) dan Hilmi (2006) dengan hasil tidak berpengaruh secara signifikan. Variabel suku bunga rata-rata kredit dipilih dikarenakan masih sedikit penelitian yang menggunakan variabel makroekonomi tersebut.

Berdasarkan research gap dan kajian teoritis di atas, maka penelitian ini bertujuan untuk menguji apakah variabel deposito mudharabah, keuntungan bagi hasil, tingkat bagi hasil dan suku bunga rata-rata kredit berpengaruh terhadap pembiayaan bank syariah (pembiayaan mudharabah dan musyarakah).

\section{METODE}

Penelitian ini merupakan penelitian kuantitatif dengan data yang digunakan adalah laporan keuangan publikasi semesteran bank umum syariah di Indonesia tahun 2010-2012. Populasi penelitian ini berjumlah 11 bank umum syariah dengan teknik pemilihan sampel yang digunakan dengan purposive sampling yaitu dengan tujuan mendapatkan sampel yang representatif sesuai dengan kriteria yang telah ditentukan. Metode analisis data yang digunakan adalah analisis statistik deskriptif dan analisis regresi linier berganda untuk pengujian hipotesis penelitian. Sebelum dilakukan ji hipotesis penelitian maka didahului dengan pengujian Asumsi Klasik (uji heteroskedastisitas, autokorelasi, dan multikolonieritas) sebagai syarat dipenuhinya unbiased model (model harus bersifat BLUE_Best Linier Unbias ES - $^{-}$ timator) dalam penelitian ini. Alat analisis yang digunakan adalah SPSS (Statistical Package for Social Science) versi 21.

Selanjutnya, definisi operasional dan pengukuran variabel penelitian ini dilakukan sebagai berikut:

1. Pembiayaan Berbasis Bagi Hasil (Y)

Pembiayaan berbasis bagi hasil yang berlaku di Indonesia adalah akad mudharabah dan akad musyarakah. Variabel pembiayaan berbasis bagi hasil mengacu pada penelitian Andraeny (2011) dan Ambarwati (2008) yang diukur dengan skala rasio yaitu jumlah agregat nilai pembiayaan mudharabah dan musyarakah yang disalurkan oleh bank syariah.

2. Deposito Mudharabah (X1)

Deposito mudharbah adalah simpanan yang penarikannya hanya dapat dilakukan pada waktu tertentu sesuai dengan perjanjian nasabah dengan penyimpan dengan akad mudharabah. Diukur dengan skala rasio dengan pengukurannya adalah besarnya deposito mudharabah yang dihimpun dari dalam negeri maupun luar negeri. 
Faktor-

Faktor yang

Mempengaruhi

440
3. Keuntungan Bagi Hasil (X2)

Keuntungan bagi hasil adalah profit yang didapat dari pembiayaan bagi hasil yang telah disalurkan oleh bank umum syariah kepada nasabah peminjam. Keuntungan bagi hasil terdapat pada Iaporan laba rugi kelompok pendapatan dengan menggunakan skala rasio, dengan pengukurannya yaitu total pendapatan dari penyaluran pembiayaan berbasis bagi hasil. Pengukuran variable ini mengacu pada penelitian yang dilakukan oleh Maryanah (2006), dimana pengukuran keuntungan bagi hasil adalah sebagai berikut:

$$
\text { Return }=P B M d+P B M S
$$

Keterangan:

PBMd = Pendapatan Bagi Hasil Pembiayaan Mudharabah

PBMs = Pendapatan Bagi Hasil Pembiayaan Musyarakah

4. Tingkat Bagi Hasil (X3)

Tingkat bagi hasil (equivalen rate) adalah rata-rata tingkat imbalan atas pembiayaan mudharabah dan musyarakah bagi bank syariah pada saat tertentu (Andraeny, 2011). Dinyatakan dalam bentuk persentase dengan skala rasio. Pengukuran dari variabel ini adalah

$$
\text { Tingkat Bagi Hasil }=\frac{\text { bagi hasil yang diterima }}{\text { jumlah pembiayaan basis bagi hasil }} \times 100 \%
$$

5. Suku Bunga Rata-Rata Kredit (X4)

Suku bunga bank umum yang digunakan dalam penelitian ini adalah suku bunga kredit yang diperuntukkan untuk investasi. Hal ini karena Bank U mum Syariah mengelompokkan pembiayaan berbasis bagi hasil ke dalam jenis investasi. Pengukuran variabel penelitian ini mengacu penel itian Anggraeni (2005), dimana variabel ini diukur dalam bentuk presentase yang merupakan suku bunga rata-rata kredit untuk investasi bank umum. Data suku bunga rata-rata kredit untuk investasi bank umum diperoleh dari data BPS mengenai suku bunga kredit.

\section{HASIL DAN PEMBAHASAN}

\section{Statistik Deskriptif}

\begin{tabular}{lrrrrr}
\hline & N & Minimum & Maximum & Mean & $\begin{array}{c}\text { Std. } \\
\text { Deviation }\end{array}$ \\
\hline Pemb.Bagi Hasil & 42 & 36351 & 15045617 & 3241067,93 & 4328377,540 \\
DepositoMudharabah & 42 & 93144 & 25016940 & 6711868,12 & 7544507,939 \\
KeuntunganBagiHasil & 42 & 815 & 1236346 & 259736,60 & 380207,353 \\
TingkatBagiHasil & 42 &, 01 &, 21 &, 0764 &, 04113 \\
SukuBunga & 42 & 11,32 & 12,85 & 12,0633 &, 51145 \\
\hline
\end{tabular}

Sumber: Data diolah, 2014

Hasil statistik deskriptif pembiayaan berbasis bagi hasil menunjukkan bahwa nilai minimum pembiayaan berbasis bagi hasil adalah sebesar $R p$ terdapat pada Bank Syariah Mega Indonesia pada semester kedua tahun 2012. Sedangkan nilai maksimum pembiayaan berbasis bagi hasil sebesar Rp 15.045.617 juta yaitu terdapat pada Iaporan keuangan Bank Muamalat Indonesia semester kedua tahun 2012. Hasil analisis statistik deskriptif deposito mudharabah memiliki nilai minimum sebesar Rp 93.144 juta yang terdapat pada Bank Panin Syariah semester pertama tahun 2010 sedangkan nilai maksimum deposito mudharabah sebesar R p 25.016.940 juta pada Bank Muamal at Indonesia semester kedua tahun 2012. 
Keuntungan bagi hasil pada tabel di atas adalah nilai minimum keuntungan bagi hasil Bank Umum Syariah sebesar Rp 815 juta yang terdapat pada Bank Central Asia Syariah pada semester pertama tahun 2010. Sedangkan nilai maksimum keuntungan bagi hasil Bank Umum Syariah sebesar Rp 1.236.346 juta oleh Bank Muamalat Indonesia pada semester kedua tahun 2012. Nilai minimum tingkat bagi hasil adalah sebesar 0,01\% yaitu terdapat pada Bank Central Asia Syariah semester pertama tahun 2010 dan BNI Syariah semester kedua tahun 2010. Sedangkan nilai maksimum tingkat bagi hasil adalah sebesar 0,21\% yaitu terdapat pada Bank Syariah Mega Indonesia pada semester kedua tahun 2011. Sedangkan nilai minimum suku bunga rata-rata pinjaman sebesar 11,32 yang terdapat pada suku bunga rata-rata pinjaman bank umum semester kedua tahun 2012. Sedangkan nilai maksimum suku bunga rata-rata pinjaman sebesar 12,85 yang terdapat pada semester pertama tahun 2010. Berdasarkan data tersebut dapat dilihat bahwa rata-rata Bank Umum di Indonesia rata-rata menetapkan suku bunga rata-rata pinjaman sebesar $12,06 \%$.

\section{Uji Asumsi Klasik}

Berdasarkan hasil pengujian Normalitas data dan Asumsi Klasik yang terdiri dari Uji Autokorelasi, uji Heteroskedastisitas, dan Multikolinearitas secara ringkas disajikan pada tabel 2 berikut ini:

\begin{tabular}{lccc}
\hline \multicolumn{1}{c}{ Model } & $\begin{array}{c}\text { Unstandardized Coefficients } \\
\text { (Beta) }\end{array}$ & Sig. & VIF \\
\hline (constant) & $-3301698,320$ & 0,225 & \\
DepositoMudharabah & 0,058 & 0.138 & 8,332 \\
KeuntunganBagi Hasil & $-0,064$ & 0,933 & 8,116 \\
TingkatBagiHasil & $-888546,298$ & 0,733 & 1,116 \\
Suku Bunga & 312054,799 & 0,154 & 1,118 \\
& & & \\
Kolmogorov Smirnov & $N=42$ & & \\
Durbin Watson Test & Asymp.Sig. 2 (tailed $)=0.348$ & & \\
\hline
\end{tabular}

Tabel 2. Ringkasan Hasil Uji Asumsi Klasik
Tabel 2 di atas menunjukkan bahwa nilai asymp 2.tailed sebesar 0,348 atau lebih besar dari 0,05 (5\%) sehingga dapat disimpulkan bahwa data residual dalam penelitian ini berdistribusi normal. Berikutnya Uji autokorelasi diperoleh nilai Durbin Watson Test sebesar 1,878 dengan dl dan du sebesar 1,3604 dan 1,7202. Nilai durbin watson memenuhi kriteria $\mathrm{du}<\mathrm{dw}<4$-du, sehingga dapat disimpulkan bahwa hasil pengolahan data dalam penelitian ini terbebas dari masalah autokorelasi. Model regresi dalam penelitian ini terbebas dari masalah heteroskedastisitas. Dimana uji glejser dapat dilihat nilai signifikansi masingmasing variabel independen yang ditunjukkan dengan angka signifikansi unstandardized coefficient beta adalah $0,225,0.138,0,933,0,733$, dan 0,154 yang lebih besar dari tingkat signifikansi 0,05. Selain itu juga diketahui bahwa nilai VIF dari seluruh variabel independen adalah 8,332, 8,116, 1,116, dan 1,118 yang menunjukkan nilai VIF $<10$. Dengan demikian dappat disimpulkan bahwa tidak terkena gangguan multikolinearitas.

\section{Uji Hipotesis}

Berdasarkan hasil pengujian hipotesis penelitian secara ringkas disajikan pada tabel 3 berikut ini: 


\section{Faktor- \\ Faktor yang \\ Mempengaruhi}

442

Tabel 3. Ringkasan Hasil Uji Hipotesis

\begin{tabular}{|c|c|c|}
\hline \multirow[t]{2}{*}{ Model } & $\begin{array}{c}\text { Unstandardized } \\
\text { Coefficients }\end{array}$ & \multirow[t]{2}{*}{ Sig. } \\
\hline & B & \\
\hline (Constant) & $-4418533,474$ & 0,351 \\
\hline DepositoMudharabah & 0,406 & 0,000 \\
\hline KeuntunganBagiHasil & 3,451 & 0,013 \\
\hline TingkatBagiHasil & $-12994238,153$ & 0,007 \\
\hline SukuBunga & 416935,115 & 0,273 \\
\hline F hitung & 142,098 & \\
\hline Sig. & 0.000 & \\
\hline
\end{tabular}

Sumber: Data diolah, 2014

Berdasarkan tabel 3 di atas diketahui nilai F hitung sebesar 142,098 dengan signifikansi sebesar 0,000 yang kurang dari tingkat signifikansi $\alpha=5 \%$. Hal ini artinya $\mathbf{H}_{1}$ diterima yaitu deposito mudharabah, keuntungan bagi hasil, tingkat bagi hasil dan suku bunga rata-rata kredit secara bersama-sama berpengaruh terhadap pembiayaan berbasis bagi hasil. Hal ini dapat dikatakan bahwa seluruh kegiatan operasional bank umum syariah dalam penyaluran pembiayaan sudah sesuai dengan teori efektifitas dan efisiensi serta memperhatikan variabel makroekonomi yang ada. Penelitian ini sesuai dengan syariah enterprise theory yang menyatakan bahwa Allah SWT. sebagai pusat segala sesuatu dan menjadi pusat tempat kembalinya manusia dan alam semesta. Oleh karena itu, manusia di sini hanya sebagai wakilNya (khalifatul fil ardh) yang memiliki konsekuensi untuk patuh terhadap semua hukum-hukum Allah dalam membawa misi menciptakan dan mendistribusikan kesejahteraan bagi manusia dan alam. Pada prinsipnya harta yang dimiliki tidak boleh ditimbun dan harus dibiarkan berputar agar harta tersebut dapat produktif dan bermanfaat bagi orang lain.

Berdasarkan tabel 3 bahwa variabel deposito mudharabah menunjukkan angka sebesar 0,406 dengan signifikansi yaitu 0,000 yang jauh lebih kecil dari 0,05 . Menyimpulkan bahwa adanya pengaruh deposito mudharabah terhadap pembiayaan berbasis bagi hasil yang artinya $\mathbf{H}_{2}$ diterima. Deposito mudharabah yang dihimpun oleh bank syariah terbukti menjadi salah satu sumber yang digunakan dalam penyaluran pembiayaan berbasis bagi hasil bank syariah. Hal ini sesuai dengan teori efektifitas yang menyatakan bahwa seberapa jauh target yaitu kuantitas, kualitas dan waktu telah tercapai dengan maksimal. Dimana makin besar presentase target yang dicapai, makin tinggi efektifitasnya. Dalam proses penyaluran dana bank umum syariah sudah dapat dikatakan efektif karena segala seluruh sumber daya bank syariah yaitu dana, dalam penelitian ini adalah deposito mudharabah dapat digunakan secara maksimal untuk penyaluran pembiayaan. Hasil penelitian ini sesuai dengan penelitian Makiyan (2001) yang menyatakan bahwa semakin besar dana yang dihimpun maka semakin besar dana yang disalurkan. Selain itu penelitian ini sesuai juga sesuai dengan penelitian Maryanah (2006) dan Andraeny (2011) yang menyatakan bahwa pembiayaan berbasis bagi hasil yang disalurkan oleh bank syariah salah satunya dipengaruhi oleh dana yang dihimpun oleh bank syariah dari masyarakat. Dengan demikian apabila bank syariah dapat mengajak para masyarakat menyimpan dananya pada bank syariah maka akan semakin banyak pembiayaan yang akan disalurkan oleh bank syariah. Apabila hal ini terjadi maka memberikan dampak kontribusi yang diberikan oleh bank syariah terhadap perekonomian Indonesia semakin besar. Hal ini dikarenakan semakin meningkatnya jumlah pembiayaan berbasis bagi hasil yang disalurkan masyarakat, maka juga dapat mendorong berkembangnya sektor riil di Indonesia. 
Berdasarkan hasil pengujian hipotesis pada tabel 3 dapat dapat diketahui variabel keuntungan bagi hasil menunjukkan angka sebesar 3,451 dengan signifikansi yaitu 0,013 yang lebih kecil dari tingkat signifikansi 0,05. Hal ini artinya $\mathbf{H}_{3}$ diterima yaitu keuntungan bagi hasil berpengaruh terhadap pembiayaan berbasis bagi hasil. Keuntungan bagi hasil merupakan salah satu faktor yang menjadi pertimbangan dalam penyaluran pembiayaan berbasis bagi hasil. Hal ini sesuai dengan teori efisien yang menjelaskan bahwa semakin besar output dibanding input, maka semakin tinggi tingkat efisiensi suatu organisasi. Semakin besar pembiayaan berbasis bagi hasil yang disalurkan, apabila asumsi usaha akan berjalan lancar dan seluruh kondisi ekonomi stabil, maka semakin tinggi keuntungan bagi hasil yang akan diperoleh bank umum syariah. Sehingga semakin tinggi keuntungan bagi hasil yang didapat dapat memacu bank umum syariah untuk meningkatkan pembiayaan berbasis bagi hasil yang disalurkan. Penelitian ini sejalan dengan penelitian Maryanah (2006) yang menyatakan bahwa adanya hubungan dua arah antara pembiayaan berbasis bagi hasil dengan keuntungan bagi hasil yang diperoleh, yaitu pembiayaan berbasis bagi hasil akan mempengaruhi profit, dan profit akan mempengaruhi pembiayaan berbasis bagi hasil. Diperkuat oleh penelitian Anggraeni (2005) yang menyatakan bahwa adanya hubungan timbal balik antara pembiayaan berbasis bagi hasil dengan keuntungan yang diperoleh.

Berdasarkan hasil pengujian hipotesis pada tabel 3 dapat diketahui variabel tingkat bagi hasil menunjukkan angka sebesar -12994238,153 dengan signifikansi yaitu 0,007 yang lebih kecil dari 0,05. Hal ini artinya $\mathbf{H}_{4}$ diterima yaitu tingkat bagi hasil berpengaruh terhadap pembiayaan berbasis bagi hasil. Secara teori bank sebagai entitas bisnis dalam menjalankan operasionalnya yang bersifat profit oriented mengharapkan tingkat keuntungan yang tinggi. Bank syariah yang juga mengedepankan profit menjadikan tingkat bagi hasil menjadi salah satu faktor yang cukup penting dalam mempengaruhi penyaluran pembiayaan berbasis bagi hasil karena pembiayaan berbasis bagi hasil merupakan jenis akad yang bersifat Natural Uncertainty Contract (Karim, 2007). Tingkat bagii hasil merupakan salah satu faktor yang menjadi pertimbangan dalam penyaluran pembiayaan berbasis bagi hasil. Hal ini sesuai dengan teori efisien yang menjelaskan bahwa semakin besar output dibanding input, maka semakin tinggi tingkat efisiensi suatu organisasi. Semakin besar tingkat bagi hasil yang ditetapkan oleh bank syariah maka akan memacu bank syariah dalam menyalurkan pembiayaan berbasis bagi hasil. Hasil penelitian ini didukung oleh penelitian dari Ambarwati (2008) dan Andraeny (2011).

Berdasarkan hasil pengujian hipotesis pada tabel 3 dapat diketahui variabel suku bunga rata-rata kredit menunjukkan angka sebesar 416935,115 dengan signifikansi yaitu 0,273 yang lebih tinggi dari tingkat signifikansi 0,05 . Hal ini artinya $\mathbf{H}_{5}$ ditolak yaitu tingkat suku bunga rata-rata kredit tidak berpengaruh terhadap pembiayaan berbasis bagi hasil. Bank umum syariah dalam menyalurkan pembiayaan berbasis bagi hasil tidak terlalu memperhatikan variabel kondisi makroekonomi yaitu tingkat suku bunga rata-rata kredit bank konvensional. Hal ini dikarenakan nasabah yang menjadi target konsumen bank syariah pada umumnya adalah nasabah yang syariah minded yang pada umumnya tidak memperdulikan besarnya tingkat nisbah atau marjin keuntungan karena pertimbangan utamanya adalah kepentingan kebutuhan Islam (Pratin, 2005). Hasil dari penelitian ini sejalan dengan penelitian Asyari (2004) dan Pratin (2005) yang juga menyatakan bahwa suku bunga rata-rata kredit tidak berpengaruh terhadap pembiayaan berbasis bagi hasil yang disalurkan. Hal ini juga dikarenakan dalam menetapkan marjin keuntungan bank umum syariah mengacu pada tingkat suku bunga rata-rata pinjaman bank konvensional dan juga mempertimbangkan tingkat marjin keuntungan rata-rata pada perbankan syariah sebagai kompetitor langsung. 
Faktor-

Faktor yang

Mempengaruhi

\section{SIMPULAN}

Berdasarkan hasil penelitian menunjukkan bahwa terdapat pengaruh secara simultan antara deposito mudharabah, keuntungan bagi hasil, tingkat bagi hasil dan suku bunga rata-rata kredit terhadap pembiayaan berbasis bagi hasil. Secara parsial variabel deposito mudharabah, keuntungan bagi hasil dan tingkat bagi hasil berpengaruh terhadap pembiayaan berbasis bagi hasil. Sedangkan variabel tingak suku bunga rata-rata kredit tidap berpengaruh terhadap pembiayaan berbasis bagi hasil.

Sehingga merujuk hasil dan pembahasan di atas maka peneliti saran yang dapat diberikan dalam penelitian ini adalah bagi bank umum syariah diharapkan dapat meningkatkan upaya dalam penghimpunan dana semaksimal mungkin dengan cara melakukan sosialisasi produk lebih gencar dan mengedukasi masyarakat untuk memilih produk penghimpunan dana menggunakan prinsip deposito mudharabah. Hal ini mengingat bahwa deposito mudharabah berpengaruh terhadap pembiayaan berbasis bagi hasil. Bagi peneliti selanjutnya dapat menambah variabel independen yang lain, dimana melihat hasil penelitian yang menunjukkan bahwa variabel independen dalam penelitian ini terbatas. Salah satu variabel independen yang dapat disarankan adalah variabel profit margin, inflasi dan tingkat rata-rata margin industry.

\section{DAFTAR PUSTAKA}

Ambarwati, Septiana. 2008. "Faktor-Faktor yang Mempengaruhi pembiayaan Murabahah dan Mudharabah Pada Bank Umum Syariah di Indonesia”. Tesis. Depok: PSKTTI UI.

Andraeny Dita. 2011. "Analisis Pengaruh Dana Pihak Ketiga, Tingkat Bagi Hasil, Non Performing Financing terhadap Volume Pembiayaan Berbasis Bagi Hasil pada Perbankan Syariah di Indonesia”. Dalam Simposium Nasional Akuntansi 14. Banda Aceh: Universitas Syiah Kuala.

Anggraini, Desti. 2005. "Faktor-Faktor yang Mempengaruhi Penawaran Pembiayaan Mudharabah dan Musyarakah: Studi Kasus Bank Syariah Mandiri”. Tesis. Depok: PSKTTI UI.

Antonio, M. Syafi'i. 1999. Bank Syariah: Suatu Pengenalan Umum. Jakarta: Gema Insani Press.

Ascarya, dan Diana Yumanita. 2005. Mencari Solusi Rendahnya Pembiayaan Bagi Hasil di Perbankan Syariah di Indonesia. Dalam Buletin Ekonomi Moneter dan Perbankan, Juni 2005.

Asyari, Hasyim. "Analisis Faktor-Faktor yang Mempengaruhi Pembiayaan Perbankan Syariah". Tesis. Depok: PSKTII UI.

Bank Indonesia. 2013. Statistik Perbankan Syariah Indonesia hingga Agustus 2013. Jakarta: Bank Indonesia. donesia.

Dewan Syariah Nasional. Fatwa DSN-MUI No.03/ DSN-MUI/IV/2000 tentang Deposito.

Fatwa DSN-MUI No.04/ DSN-MUI/IV/2000 tentang Murabahah.

Fatwa DSN-MUI No.07/ DSN-MUI/IV/2000 tentang Pembiayaan Mudharabah (Qiradh).

Fatwa DSN-MUI No.08/ DSN-MUI/IV/2000 tentang Pembiayaan Musyarakah. 
Hilmi. 2006. "Analisis Faktor-Faktor yang Mempengaruhi Pembiayaan Mudharabah pada Bank Syariah (studi kasus pada Bank Syariah Mandiri). Tesis. Depok: Universitas Indonesia.

Karim, Adiwarman. 2007. Bank Islam-Analisis Fiqih dan Keuangan. Jakarta: PT. Raja Grafindo Persada.

Makiyan, Seyed Nezamaddin. 2001. "The Role of Rate of Return on Loans in the Islamic Banking System of Iran". International Journal of Islamic Financial Service, Volume 3 (3).

Maryanah. 2006. "Faktor-faktor yang Mempengaruhi Pembiayaan Bagi Hasil di Bank Syariah Mandiri”. Tesis. Depok: PSKTTI UI.

Pratin dan Akhyar Adnan. 2005. Analisis Hubungan Simpanan, Modal Sendiri NPL, Prosentase Bagi Hasil dan Markup Keuntungan Terhadap Pembiayaan pada Perbankan Syariah Studi Kasus Pada Bank Muamalat Indonesia (BMI). Dalam Jurnal Sinergi, Kajian Bisnis dan Manajemen. Hal 35-52.

Rukmana, Amir Machmud. 2010. Bank Syariah: Teori, Kebijakan dan Studi Empiris di Indonesia. Jakarta: Erlangga

Undang-Undang Republik Indonesia No. 10 tahun 1998 tentang Perbankan sebagai Perubahan Undang-Undang No.7 tahun 1992.

Undang-Undang Republik Indonesia No. 21 tahun 2008 tentang Perbankan Syariah. 
